\title{
Hans Sachs Illustrated: Pamphlets and Broadsheets in the Service of the Reformation
}

\section{Rosemarie Bergmann}

Volume 17, numéro 1, 1990

URI : https://id.erudit.org/iderudit/1073152ar

DOI : https://doi.org/10.7202/1073152ar

\section{Aller au sommaire du numéro}

\section{Éditeur(s)}

UAAC-AAUC (University Art Association of Canada | Association d'art des universités du Canada)

\section{ISSN}

0315-9906 (imprimé)

1918-4778 (numérique)

\section{Découvrir la revue}

\section{Citer cet article}

Bergmann, R. (1990). Hans Sachs Illustrated: Pamphlets and Broadsheets in the Service of the Reformation. RACAR : Revue d'art canadienne / Canadian Art Review, 17(1), 9-16. https://doi.org/10.7202/1073152ar

\section{Résumé de l'article}

Les feuilles imprimées et les pamphlets illustrés de gravures sur bois ont atteint un large public à l'époque de la Réforme en Allemagne, ralliant le sentiment populaire derrière les positions de Luther par la conjonction du texte et de l'image. Un important centre d'imprimerie qui s'était aligné sur la Réforme en 1525, Nuremberg constitue le lieu de cette étude. Celle-ci examine des illustrations d'Erhard Schoen et d'autres accompagnant les textes du " cordonnier-poète " Hans Sachs, publiée entre 1524 et 1527. Formulée dans son poème Le Rossignol de Wittenberg (1523), la méthode polémique de Sachs fut poursuivie dans une gravure anonyme qui clarifie l'allégorie animale où, motivés par leur cupidité et leur attachement aux biens de ce monde, les adversaires de Luther exploitent les pauvres. On analyse dans cet article quatre dialogues en prose de Sachs, accompagnés de gravures et parus en 1524 sous forme de pamphlets dont le complément graphique de Sebald Beham pour La dispute entre un chanoine et un cordonnier est représentatif. Cette illustration présente un ecclésiastique incapable d'interpréter la Bible et un cordonnier luthérien lui démontrant la supériorité de son discernement. Toutefois, Erhard Schoen devint l'illustrateur principal de Sachs durant cette période et dans des gravures sur bois pour feuilles imprimées datant de 1524, Schoen rend plus marqué la structure antithétique des textes de Sachs. Une autre stratégie et également une autre phase de la représentation était la personnification imbue d'allusions sociales subversives, exemplifiée dans une feuille allégorique de 1525 où une gravure de Peter Flettner nous montre la Raison cajoler un âne pour qu'il se libère de l'Usure et de la Tyrannie ainsi que de l'Hypocrisie cléricale. À un moment aussi crucial dans l'histoire européenne de telles productions ont popularisé les doctrines de Luther, lesquelles préconisaient le recours aux écritures et la justification par la foi, consolidant ainsi l'appui à la Réforme.
Tous droits réservés @ UAAC-AAUC (University Art Association of Canada | Association d'art des universités du Canada), 1990
Ce document est protégé par la loi sur le droit d'auteur. L'utilisation des services d'Érudit (y compris la reproduction) est assujettie à sa politique d'utilisation que vous pouvez consulter en ligne.

https://apropos.erudit.org/fr/usagers/politique-dutilisation/ 


\title{
Hans Sachs Illustrated: Pamphlets and Broadsheets in the Service of the Reformation*
}

\author{
ROSEMARIE BERGMANN
}

Carleton University

\section{RÉSUMÉ}

Les feuilles imprimées et les pamphlets illustrés de gravures sur bois ont atteint un large public à l'é poque de la Réforme en Allemagne, ralliant le sentiment populaire derrière les positions de Luther par la conjonction du texte et de l'image. Un important centre d'imprimerie qui s'était aligné sur la Réforme en 1525, Nuremberg constitue le lieu de cette étude. Celle-ci examine des illustrations d'Erhard Schoen et d'autres accompagnant les textes du "cordonnier-poète " Hans Sachs, publiée entre 1524 et 1527 . Formulée dans son poème Le Rossignol de Wittenberg (1523), la méthode polémique de Sachs fut poursuivie dans une gravure anonyme qui clarifie l'allégorie animale où, motivés par leur cupidité et leur attachement aux biens de ce monde, les adversaires de Luther exploitent les pauvres. On analyse dans cet article quatre dialogues en prose de Sachs, accompagnés de gravures et parus en 1524 sous forme de pamphlets dont le complément graphique de Sebald Beham pour La dispute entre un chanoine et un cordonnier est représentatif. Cette illustration présente un ecclésiastique incapable d'interpréter la Bible et un cordonnier luthérien lui démontrant la supériorité de son discernement. Toutefois, Erhard Schoen devint l'illustrateur principal de Sachs durant cette période et dans des gravures sur bois pour feuilles imprimées datant de 1524, Schoen rend plus marqué la structure antithétique des textes de Sachs. Une autre stratégie et également une autre phase de la représentation était la personnification imbuc d'allusions sociales subversives, exemplifiée dans une feuille allégorique de 1525 où une gravure de Peter Flettner nous montre la Raison cajoler un âne pour qu'il se libère de l'Usure et de la Tyrannie ainsi que de l'Hypocrisie cléricale. A un moment aussi crucial dans l'histoire européenne de telles productions ont popularisé les doctrines de Luther, lesquelles préconisaient le recours aux écritures et la justification par la foi, consolidant ainsi l'appui à la Réforme.
No historian can ever know the emotional state of the German people on the eve of the Reformation unless he has assimilated most thoroughly the world of images of this time. Similarly, no art historian can make bold to believe that his study of these images is exhausted with research on artistic and stylistic problems. ${ }^{1}$

This wise statement was made by the German art historian Georg Dehio in 1914, but his advice has scarcely been heeded until most recently, as a perusal of the literature demonstrates. One reason for the paucity of multidisciplinary approaches is the common yet incorrect belief that, because all reformers were hostile toward religious images, German art declined rapidly and Protestant art did not exist. ${ }^{2}$ In this connection it should be borne in mind that the atelier of Lucas
Cranach the elder, the Reformation artist par excellence, flourished until the time of his son's death in 1586 and that a whole new category of evangelical images was created in response to Luther's teachings. ${ }^{3}$ A nother reason is the relative inaccessibility of and indifference to the contemporary production of popular prints, which are by far the most interesting sources for the understanding of the turbulent early sixteenth century in Germany. ${ }^{4}$ For a long time the evaluation of this branch of graphic work suffered from unfair comparison with the achievements of Dürer and his well-known contemporaries. Admittedly, the woodcuts are rarely great works of art but, geared to popular consumption, they helped frame the debate. In their combination of text and image, 
the broadsheets or broadsides and pamphlets give a lively account of Luther, his writings on religious and societal reform, of his adversary, the Catholic Church, and of the concerns of the German people in a period of great social unrest and fermentation.

The Reformation broadsheet is such a multifaceted, large and unwieldy subject that its purpose and function may best be investigated in a restricted field. The limitation of this study to one city, one writer, and a few illustrating artists is therefore deliberate.

Nuremberg has been selected on various grounds. Since the last decades of the fifteenth century it harboured a considerable printing activity under the leadership of Anton Koberger, who elevated the quality of the illustrative woodcut. Nuremberg espoused the Lutheran cause early and became one of the first imperial cities to accept the Reformation in 1525. Moreover, this gradual acceptance took place without violence, major incidents and any enforced promotion or suppression of the movement. ${ }^{5}$ Indeed, the city council had always been extremely careful not to act arbitrarily but, in consultation with the best minds among the religious parties, the humanists, and the community at large, to carry out reforms smoothly and to control any fanatic or revolutionary stirrings within its walls. ${ }^{6}$ Thus, there was neither much room nor need in Nuremberg for the inciting, volatile, and often coarse broadsheets of which Max Geisberg, their most illustrious inventorist, once said, "It is unlikely that anyone will enjoy contemplating them."

The choice of Hans Sachs is also an obvious one, for he is perhaps the best-known literary figure associated with the broadsheet, even beyond the hometown which he never left after his journeyman years. ${ }^{8}$ Röttinger's invaluable inventory lists more than 100 Bilderbogen (literally, picture sheets) with his texts. ${ }^{9}$ More importantly, the experience of the Reformation and his identification with the ideas and teachings of the man from Wittenberg were a major impulse for his poetry. Sachs says in the description of his library that already in the year 1522 he owned " 40 sermons and little tracts by Luther." ${ }^{10}$ For a long time Sachs has been seen as the romantic hero of Wagner's Meistersinger, the shoemaker-poet of songs and carnival farces. Only recent literary criticism has acknowledged that some of his best writing is contained in the prose dialogues and Spruchgedichte of the 1520s. ${ }^{11}$

Erhard Schön (ca. 1491-1542), also a son of Nuremberg, was undoubtedly the most diligent designer of popular woodcuts during the Dürer era and played a pre-eminent role as illustrator of the poems of Sachs. ${ }^{12}$ Their extensive collaboration, from which about 60 broadsheets survive, began with works of Reforrnation content. Some of those were illustrated by Sebald Beham (1500-1550) before he left Nuremberg on order of the city council, which had accused him and two other "godless painters" of involvement with the cause of the radicals. Schön's artistic debt to him is such that he was named Pseudo-Beham. ${ }^{13}$

For the genesis of the Reformation broadsheet in Nuremberg it is important to know when the population was first familiarized with reform ideas. Christoph Scheurl claimed as early as 1520 in a letter to Melanchthon that not only scholars and patricians but also the majority of the citizens were on Luther's side. ${ }^{14}$

The humanist circle there read and debated his proclamations at gatherings where Johannes von Staupitz, Luther's friend, confessor and vicar general of the Augustinians, so inspired those present with his new interpretations of the Scripture that the group took the name sodalitas Staupitziana. After Luther's visit in Nuremberg in 1518 it changed to sodalitas Martiniana in support of his teaching. Willibald Pirckheiner wrote the satirical Eckius dedolatus (Eck soundly beaten up), thus backing Luther in his feud with Johannes Eck, and Lazarus Spengler, the longlime secretary of the city council, defended him with Ein Schuzred (An A pology) in $1519 .{ }^{15}$ The common people, many of whom could not read, learned of the Wittenberger and his teachings primarily through a number of excellent Augustinian preachers and administrators, most important among them Wenzeslaus Linck and Andreas Osiander. ${ }^{16}$

Although of humble origins, the shoemaker Sachs had been educated at Latin school and was relatively well-to-do with two houses to his name at the age of 30 . For a member of the lower bourgeoisie he had an extraordinary desire for learning, as the titles of his library list of 1562 indicate. ${ }^{17}$ Although he had written poetry from 1513 onward, there is no evidence that he produced anything at all between 1520 and 1523 . The implication is that he must have devoted himself entirely to the zealous study of Lutheran tracts and pamphlets which he had collected and bound in 1522. After some initial hesitation he was won over by the "evangelical truth" preached by Luther and was ready to sing his praise publicly, first with the Meisterlied, Das Walt got (May God Grant It) which, according to the mastersinger statutes, could not be printed. ${ }^{18}$ Shortly afterwards, he published an elaboration of it, Die Wittenbergish Nachtigall (The Nightingale of Wittenberg - Fig. 1). ${ }^{19}$ This paean to Luther made him popular overnight; six editions were printed in 
that year, and the title became a topos for the reformer.

The purpose of the long poem is stated in the preface: to explicate to the common, uninstructed man the pure evangelical truth (according to Luther) which had been abused too long by the Romanists (v, 40-48, 70-75). The first part sets out in terms of an animal allegory all the wrongdoings of the Church, the appearance of Luther, the attacks on him, and, finally, the victory of the unadulterated biblical truth. In the second part ( $\mathrm{v}$, 99-646), the allegory is interpreted at great length with an identification of the animals. ${ }^{20}$ Luther is the lovely nightingale who heralds the day (the gospel) and drives out the night (the old teaching). The lion is Pope Leo $\mathrm{x}$, wolves are clerics, serpents are monks and nuns, wild geese are laymen opposed to Luther, and frogs the members of the theological faculties of Paris and Louvain who in 1519 and 1521 pronounced against Luther. His personal adversaries are allegorized by the boar, the cat, the goat, the donkey, and the snail in reference to Johannes Eck, Thomas Murner, Hieronymus Emser, Alfred von Alfeld, and Johannes Cochlaeus, respectively. ${ }^{21}$ This menagerie attacks the sheep (community of Christians) and threatens the nightingale. Thus, Sachs manages to dramatize Luther's current struggles and to mock - with relish - the practices of the Catholic Church. In the clothing of the time-honoured animal fable he not only gives praise to his admired hero but also delivers the message of Luther's evangelical and polemical writings. However, his "erklerung" is rather a simplification of the Reformer's positions and dogma while the weighty arguments raised by him are reduced by Sachs to a catalogue of sins among which greed and worldliness are paramount. "Vnd wann mans bey dem liecht besicht/Jst es als auff das gelt gericht" (And when their deeds are seen by light/their only goal is money's might, v, 201-202). In rather impassioned words, running to 140 verses, Sachs accuses the Church of simony and usury, giving special emphasis to the indulgence trade. He singles out the poor as those most affected by these ecclesiastical abuses and in one of the explanatory marginal notes calls the clerics cheaters of peasants. ${ }^{22}$ Thus he participates in the mixing-up of religious with societal issues, albeit modestly, as his hero had done in the Sermon on Usury and in the Address to the Christian Nobility of the German Nation. Sachs knew these texts and was also familiar with the gravamina, discussed at the diets of 1518 and 1521 at Augsburg and Worms respectively. Yet, the central concern is religious, the purpose didactic, and the Nachtigall is more than the propaganda piece it is sometimes accused of being. ${ }^{23}$
Attention has been focused on this poem because it contains the seeds of Sachs' other Reformation-connected writing. The title-page of the first edition, although coarse in design and by an anonymous craftsman, does much to enhance the text by rendering the allegory in pictorial terms that were commonly understood. A central tree divides good and bad; to the left the sun shines brightly, the Lamb of God is surrounded by sheep with more of them lower down being milked by serpents. To the right the open-mouthed, hungry wolves are grouped with the chattering wild geese and above them hovers a darkened, waning moon; at the bottom of the tree a pool teems with frogs and the snail crawls at the edge. The nightingale's chief enemies, the goat, the cat, the boar below, and the donkey opposite, are duly emphasized by their larger size. Playing on the relations in which down $=$ bad and $u p=$ good, the fierce lion is placed directly below the nightingale who faces the sun with her song, thus effectively paralleling the end of the poem: "Christus amator/Papa peccator" (Christ the lover/Pope the sinner). This antithetical pictorial statement is the structural principle of the very popular Passional Christi et Antichristi (1521) which was written by Melanchthon and illustrated by Cranach with a short postscript, possibly written by Luther. In the 13 pairs of woodcuts, glossed with texts from the Bible and the Decretals, the lives of Christ and the pope are compared and criticism of the latter speaks mainly through the pictures. ${ }^{24}$ The Passional was surely known to Sachs and may have made him aware of the value of a good picture as an adjunct to the word.

Early in 1524 Hans Sachs employed the prose dialogue, recently revived by the humanists, in the service of contemporary polemics and it is generally acknowledged that his four Reformation dialogues count among the best of the period from a literary point of view. ${ }^{25}$ While the last two direct criticism at the overly zealous partisans of Luther, the first two share the strictly anti-Roman issues and spirit of the Nachtigall.

In the first piece, entitled Disputation Between a Canon and a Shoemaker (Fig. 2), ${ }^{26}$ he defends, as the subtitle proposes, the word of God and the right Christian way, thus championing Luther's justification through faith and Christian love. In his usual simplifying terms he treats of the three walls protecting the papacy from reform that are figures in Luther's To the Nobility. The reality and opportuneness of the little ironies with which he laces his lively dialogue explain the instant success of the piece, measurable by the extraordinarily high number of 11 editions in 1524. The canon's Bible is dusty, that is, unread, because instead he 
reads the papal Decretals; he rattles off his prayers for the hours perfunctorily, he orders the housekeeper to provide rare gamebirds for dinner and dice for amusement afterwards; his "calefactor" unveils the master's lack of biblical knowledge and declares his own Lutheran sympathies. The titlepage, with the same text from Luke 19:40 as that of the Nachtigall, is illustrated by Sebald Beham whose anti-Roman, even radical, attitude and sympathy for the peasant are evident in his work as well as in the fact that the council temporarily expelled him from the city for blasphemy and insurrection. ${ }^{27}$ As early as 1521 he had designed an Allegory on Monasticism (Fig. 3) in which a poor man, encouraged by Paupertas, forces a book, presumably the Bible, into the mouth of a monk who is pulled back by the cardinal sins Superbia, Luxuria, and Avaritia, ${ }^{28}$ clearly implying that the poor man is the true Christian. On the title-page of Sachs's Disputation the facial features of the canon resemble those of the monk, while those of the shoemaker resemble the poor man's to a great extent. Within the limited space of the octavosized pamphlet Beham successfully expressed the essence of the dialogue with sparse means. The slightly obese canon, closely followed by a housekeeper whose movement, in parallel to his, suggests intimacy, gesticulates intensely, as if in defense, toward the shoemaker who approaches with a pair of slippers he has made for the physical comfort of the cleric. The cobbler, although standing farther back than his opponent, is taller, as if to suggest the superiority of his arguments. Sachs and his publisher must have been pleased with the design, for Beham was chosen again to illustrate the third and fourth dialogues.

In the second Sachs treats a theme in which the monastic vows of poverty, chastity, and obedience are debated by an old Franciscan, the cobbler Hans who ventures an intellectual, Biblesupported interpretation of Lutheran teachings, and the baker Peter who takes the practical position of the common man. ${ }^{29}$ Here again Luther's theological complexities are evaded in favour of praising bourgeois virtues and condemning monasticism that practises "armut on mangel/und keüschait die besudelt ist/vnd gehorsam/die erticht ist" (Poverty without want/chastity that is defiled/and obedience/that is feigned, v, 34l-43). Eyn gesprech von den Scheinwercken der Gaystlichen (A Conversation Concerning the False Good Works of the Clergy-Fig. 4) is less aggressive in tone and, with seven editions in 1524 , never reached the popularity of the first dialogue. Its title-cut marks the beginning of the fruitful collaboration between Hans Sachs and Erhard Schön, who became Sachs's principal illustrator. It shows the old monk and a younger brother under the arched entrance to a room in which Peter and Hans sit at table. The three participants of the "gesprech" are identified by the traditional speaking gestus of their hands, but their configuration does more than merely illustrate the scenario. Peter occupies the centre of the room, for it is to his house that the monks have come to beg for candles, though they already have a basketful. This subtly hints at their greed while their corpulence belies a commitment to poverty. Not Peter but Hans is turned in their direction as the weightier voice in the conversation and both occupy twice as much space as the friars, thus signifying the merit of the evangelical viewpoint they represent. The most important pictorial message appears as disguised symbolism ${ }^{30}$ in the form of the meagre meal in front of Peter and Hans. The bread and wine stand for the body and blood of Christ, which the clerics slander with their falsity, as can be read in the title above the print: "A conversation on the hypocritical ways of the clerics and their vows with which they mock the blood of Christ and yet hope for salvation." One may be almost certain that this representation deliberately refers to Luther's doctrine of the communio sub utraque forma (communion under both kinds), which is also the theme in Dürer's woodcut, the Last Supper of 1523. In this last of his prints on the subject Dürer replaces the traditional paschal lamb of his earlier versions with a chalice and places an oversized paten prominently and centrally in the foreground of the composition, adding a bread basket and a wine jug in the righthand corner. These objects in an otherwise bare room appear to reflect Dürer's endorsement of Luther's view on the practice of the Lord's Supper, namely, that it was to be received by the congregation under both kinds, chalice as well as host. ${ }^{31}$ The bread and wine in our title-page may allude to the same Reformation issue. Since the text does not touch on this important doctrine, its depiction could be seen as Schön's own expression of Lutheranism.

Sachs did not fail to grasp the enormous potential of the broadsheet for his purposes. He admired good painting, as is known from his panegyric on Dürer, ${ }^{32}$ but whether for aesthetic reasons or on account of good craftsmanship remains a moot point. Furthermore, the language of his early writing is highly descriptive and nurtured by visual images. That he recognized the image as no less valid than the word finds support in the fact that a number of broadsheet texts were written for already existing woodcuts. ${ }^{33}$

The earliest Reformation-related Spruchgedichte in the form of broadsheets are dated to the year of the dialogues but no exact chronology can be 
established. Das Hauss des Weysen vnd das haus des vnweisen manss (The House of the Wise and the House of the Foolish Man) Math. vij. (Fig. 5) - so reads the title at the top of the shcet-interprets the parable of the wise man and the foolish man who built their houses on rock and sand, respectively. ${ }^{34}$ Sachs, whose full name and the date (15) 24 appear at the bottom of the sheet, works his text on the given antithesis and develops a kind of double dialogue between Christ and the Christians, the angel, and the godless crowd. The speeches are literally manufactured from biblical quotations, identilied in the margins, as is the practice in the Nachtigall to which this broadsheet is related not only by the principle of polarization but also by the complaint of the Christians of sufferings inflicted through the godless, and by their denial of God and his word: "We thought there is no God/and invented dogma and commandments." This comes close to the canon's dusty Bible and perfunctory recital of the hours in the first dialogue. Sachs clearly turns the parable into the same kind of anti-Catholic polemic that characterizes the Nightingale and the canon-cobbler dialogue. Erhard Schön is more explicit about the identity of the godless. The inhabitants of the crumbling house at the right are monks and nuns and the true Christians are threatened by a cardinal with a papal bull at the far left, an arrowshooting monk and an advocate pointing to a pyre. The latter two are followed by a common man who, with his sword, seems intent on defending the evangelicals. The four text columns are visually well co-ordinated with the images of Christ, the Christians, the angel, and the godless. The opposition of the two houses is formally reinforced by Christ as Saviour and the apocalyptic angel in the upper corners, both accompanied by xylographic Scripture texts. Schön more than adequately elaborated the antithesis of the houses: that of the wise stands high on the rocks with the cross reaching the clouds, its foundation is Christ, the posts are the Old and New Testaments and the cornerstonc is the Lamb of God, whereas that of the unwise is built on sand. It has no foundation; the posts in the form of the Decretals and a tome of Duns Scotus give way and it breaks up in the centre above the seven-headed dragon, the Antichrist. It is quite obvious that the illustration intensifies the message of the text and surpasses it in its antiRoman tendency.

Also dated to 1524 is the broadsheet Der schafstal Christi (Christ's Sheepfold-Fig. 6), which must have been produced in close proximity to the foregoing one. ${ }^{35}$ This time the parable of Christ the Good Shepherd as the door to the sheepfold is the scriptural basis (John 10:17-19); even the speakers are the same except for the Christians, here missing. The disputation between the angel and the godless crowd deals with the Lutheran sola fide doctrine, the redecming power of the word of God versus that of good works, thus paralleling the second dialogue. The mutual accusations and the aggressive tone of this disputation fit the popularizing function of the broadsheet. The woodcut is a copy after a lost work of Sebald Beham. Text and image are again well integrated, with Christ standing in the central doorway inviting people to enter. At left the angel with the book addresses a group of the godless. Those among them who climb and destroy the roof are - not unexpectedly-monks, nuns, and priests. The illustrator makes a further timely comment in showing a peasant and his wife as the first to enter the sheepfold. The most common representative of the church-exploited poor in contemporary broadsheets and pamphlets, the peasant is often presented as pro-I utheran. In the literature he is type-cast as "Karsthans" or Johnny of the mattock, the implement he often shoulders in pictorial representations. In the popular anonymous booklet, The New Karsthans of 1523, he proclaims proudly: "When I come home I shall buy all Lutheran books." ${ }^{36}$ It is also possible that a scholar with a goblet at right should be viewed together with the man in front of him who may be holding bread close to his mouth. If so, then the goblet would stand for the chalice and the bread for the wafer and these figures would once more allude to the sacrament under both kinds. In any case, it is important to note that the designer of the woodcut, through representations unwarranted by the text, shows his own involvement with Reformation issues and adds to the popular appeal of the sheet.

In the third broadsheet of this group, Ein neuwer Spruch iwie die Geystlichkeit vnd etlich Handtwercker vber den Luther clagen (A New Poem Concerning the Complaints of Clergy and Some Trades against Luther - Fig. 7), Sachs addresses a social issue ${ }^{37}$ Clergy and tradespeople complain to Christ about "Martin Luther the harmful man who has upset all of Germany with his writing and teaching" and who through his church reform has deprived them of work. The list of trades goes from stationers to priests' concubines and mentions everyone connected with "church building, decorations and ornaments which are scorned by him (Luther)." Sachs calls all plaintiffs godless at the top of their column and in the corresponding part above the print their complaint is said to be motivated by greed. Luther answers proudly that he unveils "their great greed and simony, their false worship and double-dealings." He goes on to compare them to Demetrius of Acts 19:24-28, 
whose action was also dictated by greed. Christ, instead of strictly judging the case, adds with his words to the previous accusations so that Sachs with his text essentially reiterates his simple antiCatholic polemic and admiration for Luther. There is no sign in the text of an awareness of the contemporary image controversy, although Luther had pronounced himself against Carlstadt's iconoclastic manoeuvres already in 1522 with the Eight Sermons from Wittenberg. The issue is addressed in a slightly later broadside entitled Klagrede der armen verfolgten Götzen und Tempelbilder... (Complaint of the Poor, Persecuted Idols and Temple Images-Fig. 8) and illustrated by Erhard Schön. Here, in similarly simplistic terms, the worldly man at right, who is followed by two women and orders the removal, smashing, and burning of statues, is shown with money bag, wineflask, and the biblical beam in his eye as greedy and hypocritical. ${ }^{38}$

Ein neuwer Spruch bears no date but was produced late in the year 1524. The accompanying woodcut by Sebald Beham opposes the parties effectively with God the Father in the clouds. The lawyer at left is followed by a maker of church hangings, a nun, a bell-founder, and two monks behind them. Their fine dresses and fur hats mock their complaint. Among their opposite numbers, led by Luther with the Bible, the artist has again singled out the peasant who stands in the forefront, shouldering a flail, and declaring himself a Lutheran by his gesture. Beham may well have intended to express his sympathies with the peasants, a stance that contributed to his difficulties with the Nuremberg council. Considering the strict symmetry of the composition, it is also conceivable that the direct juxtaposition of the bell at left and the food basket at right is meant to refer to Luther's well-known statement that the poor are living temples to whom sustenance should be given. Undoubtedly, this fine print carries a more effective message than the wordy text of Sachs.

Regarding the date of this broadsheet the following points can be made. First, its text was printed with the same types as Sachs's third Reformation dialogue of 29 September 1524. Secondly, the figures of peasant and advocate are taken directly and reversed from a six-block woodcut after a fifteenth-century tapestry found at Michelfeld on the Rhine on 24 March 1524, according to an inscription at its top (Fig. 9). It is generally attributed to Dürer or his workshop. ${ }^{39}$ As Beham was a close follower of the great master, he may well have had access to the original drawing after the textile and could have copied the figures for the Sachsian broadsheet. This makes a date toward the end of 1524 a distinct possibility. ${ }^{40}$
It has been claimed that Hans Sachs ceased to engage in Reformation polemics in 1527 after the Nuremberg city council reprimanded him for the notorious Ein wunderliche weissagung/von dem Bapstumb (A wondrous prophesy/of the papacy), a pope-slandering, illustrated pamphlet for which the preacher Andreas Osiander was responsible, having secured Sachs's collaboration in the form of four-line explanatory rhymes below the woodcuts. ${ }^{41}$ Shown here is the pope watching the battle between dove and serpent, symbols of the holy spirit and the devil. The verses are actually quite mild and the council's warnings restrained in telling the poet to stick to his trade of shoemaking and refrain from issuing similar poems. ${ }^{42}$ However, there is ample evidence from later Sachsian broadsheets that he did not heed the warning. Yet it can be demonstrated that, once the Reformation became a reality in Nuremberg in 1525, he gradually directed the criticism of his "kampffgesprech" and "klagred" away from the iniquities of the Catholic Church to those of the society at large. Similarly, his hero worship of Luther was replaced by the proclamation of "evangelical truth" through the word of God.

Tyrannei, Wucher und Gleisnerei (Tyranny, Usury, and Hypocrisy - Fig. 10), an allegory of 1525 with an illustration by Peter Flötner (ca. 1485-1546), is a case in point and may be regarded as a token example of Sachs's changing attitudes. ${ }^{43}$ The "poor common donkey" who is none other than the common man is the object of persuasion. In front of him personified Reason coaxes the donkey not to stop at throwing off Hypocrisy but to do the same with Usury and Tyranny, who flay and torment him. Tearful Justice, who is in the stocks, just as she was in the Michelfeld tapestry, grieves over her helplessness, but the word of God at the right advocates patience and promises revenge, victory, and salvation. While the fallen Hypocrisy, represented by a Franciscan monk with purse in hand, is characterized as clerical ("geystliche Gleysnerey"), Usury, identified as a Jew by a yellow ring on the right shoulder, and the fully armed Tyranny, are personified as laymen and thus connected with the world of commerce and secular power. Seen in connection with the suppression of the Peasant Revolt in the summer of 1525, the allegory expresses sympathy with the plight of the common man and trust in God's saving justice.

The illustrated pamphlets and broadsheets investigated here are quite distinct from the main body of strictly slanderous and inflammatory materials of the time. Although critical of pope and clergy, their primary purpose is to communicate the evangelical message of Luther to the com- 
mon people. His tracts and sermons are clearly reflected in the Sachsian texts, especially the doctrines of justification through faith and grace over law and good works, even though their theological content is diluted. The Lutheran emphasis on the word of God is demonstrated by copious quotation and paraphrase of the Scripture. Since the accompanying woodcuts were mostly designed by major Nuremberg graphic artists, their simple and concrete images sensitively and succinctly illustrate the central issues of the text. Through juxtaposition of popular figure types the opposing ideological camps can be instantly recognized, yet even the clerical party is seldom represented in a coarse or deriding fashion. Thus, the Sachsian dialogues and Bilderbogen of the decisive years of the Reformation exercised their didactic function positively rather than negatively and in the same spirit of moderation that guided the actions of the civic authorities in Nuremberg. By virtue of the interaction of vernacular texts and comprehensible images they were instrumental in forming and influencing public opinion.

\section{NOTES}

* This material was first presented at a symposium, held by the National Gallery of Canada in 1981, the year of publication of Robert W. Scribner's pioneering For the Sake of Simple Folk: Popular Propaganda for the German Reformation, Cambridge Studies in Oral and Literate Culture, 2 (Cambridge, 1981). In connection with the quincententenary of Luther's birth several exhibitions have also included Reformation broadsheets. I dedicate this essay to my mother on her ninetieth birthday.

1 Georg Dehio, Kunsthistorische Aufsätze (Munich and Berlin, 1914), 72-73; this and all other translations by author.

2 For changed directions in research sec Carl Christensen, Art and the Reformation in Germany (Athens, Ohio, and Detroit, 1979); in particular chap. 5, "The Reformation and the Decline of German Art," 164-80. On Luther's generally positive stand toward the arts see Rosemaric Bergmann, "A 'tröstlich pictura': Luther's Attitude in the Question of Images," Renaissance and Reformation, N.S. I (1981). 15-25

3 Dieter Koepplin and Tilman Falk, Lukas Cranach, exhibition catalogue (Basel and Stuttgart, 1974), I, 29; Martin Scharfe, Evangelische Andachtsbilder (Stuttgart, 1968); Christianc D. Andersson, "Religiöse Bilder Cranachs im Dienste der Reformation," in Lewis W. Spitz, ed., Humanismus und Reformation als kulturelle Kräfte in der deutschen Geschichte (Berlin, 1981), 43-79.

4 Otto Clemen, "Die lutherische Reformation und der Buchdruck," Schriften des Vereins für Reformationsgeschichte, LVII (1939), H. 1, Nr. 167. Recently particular attention has been given to these materials in numerous publications of the former German Democratic Republic where they are often tendentiously interpreted only as documents of the early bourgeois revolution. (f. Wolfgang Hütt, Deutsche Malerei und Graphik der frühbürgerlichen Revolution (Leipzig, 1973), with extensive bibliography.

5 Bernd Möller, Reichsstadt und Reformation (Gütersloh, 1961), 33.

6 Gottfried Seebass, "The Reformation in Nuernberg," in Lawrence P. Buck and Jonathan W. Zophy, eds., The Social History of the Reformation (Columbus, 1972), 21, 30.
7 "Viel Freude wird ihre Betrachtung wohl bei niemandem hervorrufen." Quoted in Hermann Meuche and Ingeburg Neumeister, eds., Flugblätter der Reformation und des Bauernkrieges (Lcipzig, 1976). 10.

8 William Coupe, The German Illustrated Broadsheet in the Seventeenth Century (Baden-Baden, 1966), 72. For a general treatment of Sachs see Die Welt des Hans Sachs, exhibition cataloguc, Nuremberg, Stadıgeschichtliche Museen, 1976.

9 Heinrich Röttinger, Die Bilderbogen des Hans Sachs (Strasbourg, 1927).

10 Die Welt des Hans Sachs, xxviii.

11 Gerald H. Seufert, ed., Die Wittenbergisch Nachtigall (Stuttgart, 1974); and Bernd Balzer, Bürgerliche Reformationspropaganda; die Flugschriften des Hans Sachs in den Jahren 1523-1525 (Stuttgart, 1973). 1-2.

12 Heinrich Röttinger, Erhard Schön und Niklas Stör, der Pseudo-Schön (Strasbourg, 1925); and reproductions of the woodcuts in Max Geisberg, Bilderkatalog, Der deutsche linblatt-Holzschnitt des XVI. Jahrhunderts (Munich, 1930), 195-225.

13 Röttinger, Erhard Schön, 7, 12.

14 Hans von Schuberı, Lazarus Spengler und die Reformation in Nürnberg (Leipzig, 1934), 205.

15 For the best account of these matters see Harold Grimm, Lazarus Spengler, a Lay Leader of the Reformation (Columbus, 1978).

16 Seebass, in Buck and Zophy. The Social History of the Reformation, 21-23, 41-51; on Linck see Charles E. Daniel, "Hard Work, Good Work and School Work ..." in the same publication, 4l-5l.

17 Barbara Könneker, Hans Sachs (Stuttgart, 1971), 4-6.

18 A convenient edition of the song is by F. H. Ellis, Mans Sachs Studies I. Das Walt got: A Meisterlied (Bloomington, 1941). The complete oeuvre of Sachs is gathered by Adclbert von Keller and Edmund Goetze, eds., Hans Sachs. Werke, 26 vols. (Tübingen, 1870-1908).

19 Seufert, Die Wittenbergisch Nachtigall; and Balzer, Bürgerliche Reformationspropaganda, 38-72.

20 He seems to follow, at least in part, Konrad von Megenberg's Book of Nature which is on his library list and which is based on the Physiologus. In 1.524 Sachs composed a polemical broadsheet, The Twelve Pure and the Twelve Sinful Birds, illustrated by Schön where the nightingale sings of Christ, the true light. She is opposed by the magpie which is symbolically associated with monks. The print is discussed and reproduced in Christiane D. Andersson, "Polemical Prints in Reformation Nuremberg," in Jeffrey Chipps Smith, ed., New Perspectives on the Art of Renaissance Nuremberg (Austin, 1985), 57-59.

21 These identifications are not Sachsian inventions and were familiar to those involved in the Reformation debate. They are based on correspondences with the men's names or aspects of their biographies. For an extensive interpretation of these foes of I.uther sec Balzer, Bürgerliche Reformationspropaganda, 58-62.

22 The marginal note at v, 233, reads "Bawren bescheysser."

23 See Balzer, Bürgerliche Reformationspropaganda, note 17. This book is founded on a highly personal theory of propaganda and its conclusions often seem slightly forced.

24 Cf. Hildegard Schnabel, ed., Lukas Cranach d.Ae., Passional Christi et Antichristi (Berlin, 1972); and George Fleming, "On the Origin of the Passional Christi et Antichristi and Lucas Cranach the Elder's Contribution to Reformation Polemics in the Iconography of the Passional," (jutenberg Jahrbuch, XLVIII (1973), 351-68.

25 Könneker, Hans Sachs, 29

26 Seufert, Die Wittenbergisch Nachtigall, 41-47; Balzer, Bürgerliche Reformationspropaganda, 116-27; and Die Welt des Hans Sachs, Nr. 6.

27 Herbert 'Kschelletzschky, Die "dreigottlosen Maler" von Nürnberg: Sebald Beham, Bartel Beham und Georg Pencz (Leipzig, 1975), 12 and passim. 
28 Meuche and Neumeister, Flugbläter der Reformation, 44, 120; Scribner, For the Sake of Simple Folk, 42-44; and Martin Luther und die Reformation in Deutschland, exhibition catalogue, Nuremberg, Germanisches Nationalmuseum, $1983,250$.

29 Scufert, Die Wittenhergisch Nachtigall, 73-92; and Balzer, Bürgerliche Reformationspropaganda, 116-27.

30 Here used in the sense of Erwin Panofsky, Early Netherlandisch Painting, 2 vols. (Cambridge, Mass., 1964), 141 and passim.

31 Cf. Erwin Panofsky, The Life and Art of Albrecht Dürer (Princeton, 1955), 221-23.

32 Hans Sachs, Katalog zur Ausstellung in der Kunstsammlung der Universität Göttingen, 4. bis 22. Februar 1976 (Göttingen, 1979), 8-10.

33 Helene Henze, Die Allegorie bei Hans Sachs mit besonderer Berücksichtigung ihrer Beziehungen zur graphischen Kunst (Halle, 1912), 24.

34 Meuche and Neumeister, Flugblätter der Reformation, 30-31, 115-16; Balzer, Bürgerliche Reformationspropaganda, 76-80; Scribner, For the Sake of Simple' Folk, 193-95; and Martin Luther und die Reformation, 242.

35 Meuche and Neumeister, Flughlatter der Reformation, 34, 116-17; Balzer, Bürgerliche Reformationspropaganda, 80-85; Scribner, For the Sake of Simple Folk, 51-53; and Martin L.uther und die Reformation, 241.

36 Arnold E. Berger, Die Sturmtruppen der Reformation (Leipzig, 1931), 55; Kurt Uhrig, "Der Bauer in der Publizistik der Reformation bis zum Ausgang des Bauernkrieges," Archiv für Religionsgeschichte, xxxIII (1936), 70-125; and Keith P. F. Moxey, Peasants, Warriors and Wives: Popular Imagery of the Reformation (Chicago and London, 1989), 57-58.

37 Balzer, Bürgerliche Reformationspropaganda, 74-76; Herbert Zschelletzschky, "Drei Sozialsatiren der 'gottlosen Maler' von Nürnberg," Jahrbuch für Volkskunde, vII (1961), 46-74; Scribner, For the Sake of Simple Folk, 30-32; Martin Luther und die Reformation, 251; and Moxey, Peasants, Warriors and Wives v, 57-58.

38 Röttinger, Erhard Schön, 127, Nr. 147; and Meuche and Neumeister, Flugblatter der Reformation, 91.

39 For attributions see Panofsky, Dürer, 391. The iconography and social implications are discussed by Wilhelm Fränger, "Der Teppich von Michelfeld," Jahrbuch für Volkskunde. I (1955), 183-211; Martin Luther und die Reformation, 252.

40 Balzer, Bürgerliche Reformationspropaganda, 74, argues for an earlier date still in 1523 which would fit his construct of Sachs's changing propaganda concept better.

41 The pamphlet is owned by the Niedersächsische Staatsund Universitätsbibliothek, Göttingen.

42 Hans Sachs, catalogue Göttingen, 25.

43 Meuche and Neumeister, Flugblatter der Reformation, 57, 121-22; Martin Luther und die Reformation, 251: Konrad Hoffmann, "Iypologie, Exemplarik und reformatorische Bildsatire," in Josef Nolte, et al., eds., Kontinuität und Umbruch ('Tübingen, 1978), 189-210. 


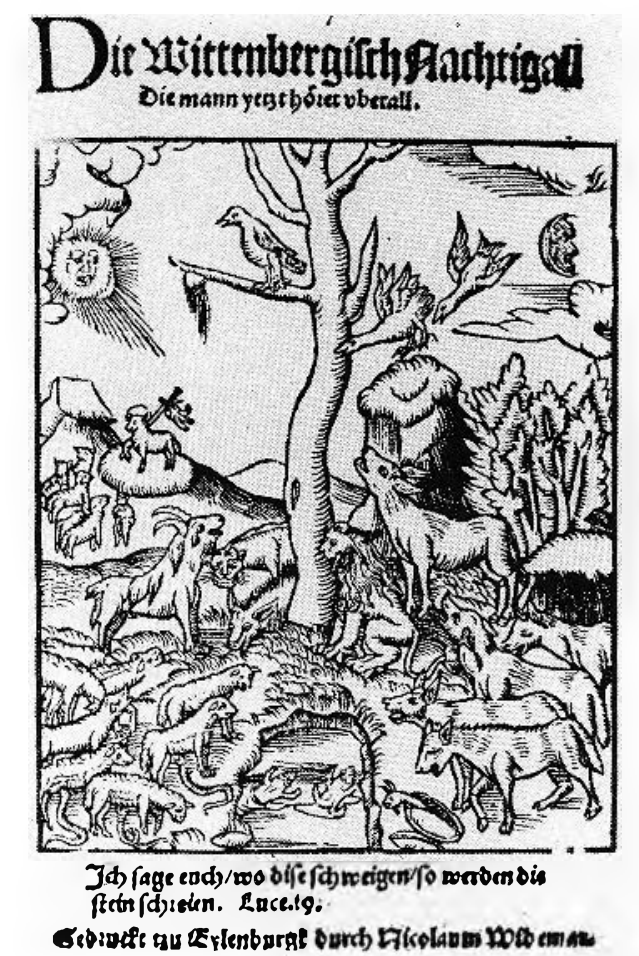

Figure 1. Anonymous. Die Wittenbergisch Nachtigall, Ist ed., 1523, title-page (Photo: Göttingen, L'niversitätsbibliothek).

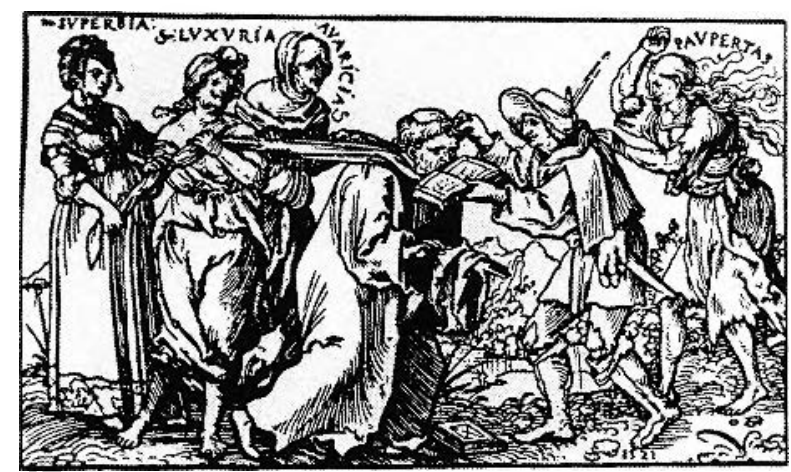

Figure 3. Sebald Beham. Allegory auf das Mönchstum, 1521, single-leaf woodcut (Photo: Munich, Staatliche Grapische Sammlungen).
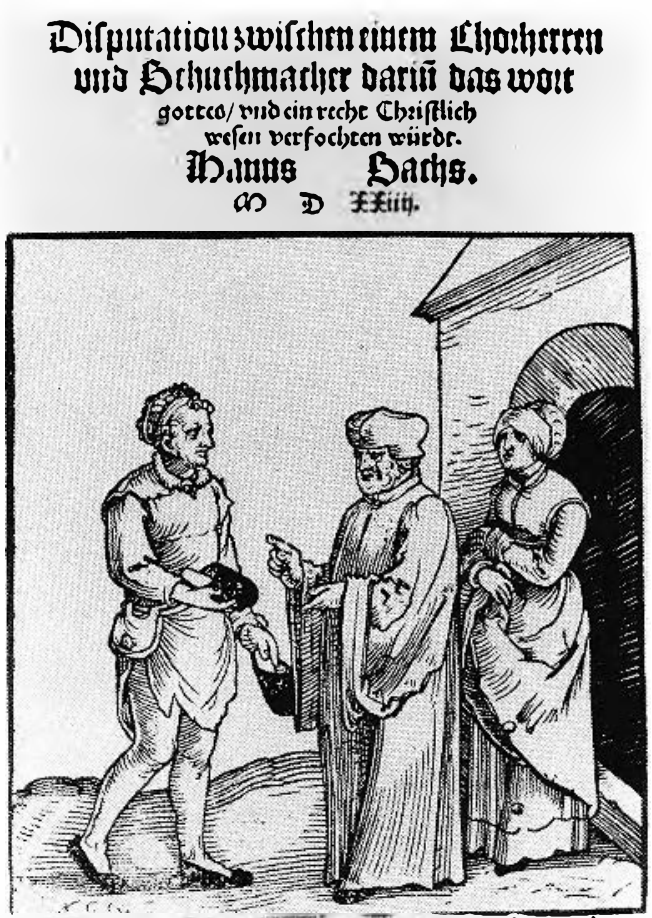

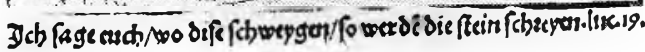

Figure 2. Sebald Beham. Disputation zwischen einem Chorherrn und Schuhmacher, 1524, titlepage (Photo: Nuremberg, Stadtbibliothek).

\section{EYn gerpacch vō oen Schernavercliê. ber Gayfliden/ond jren gelïbotenroamit fิ 3 ûuteclefterung Oes Blăts Chsif $i$ verm.zynen/eligzinweroen. \\ Ђans Sadp. Gdủ|zer.}

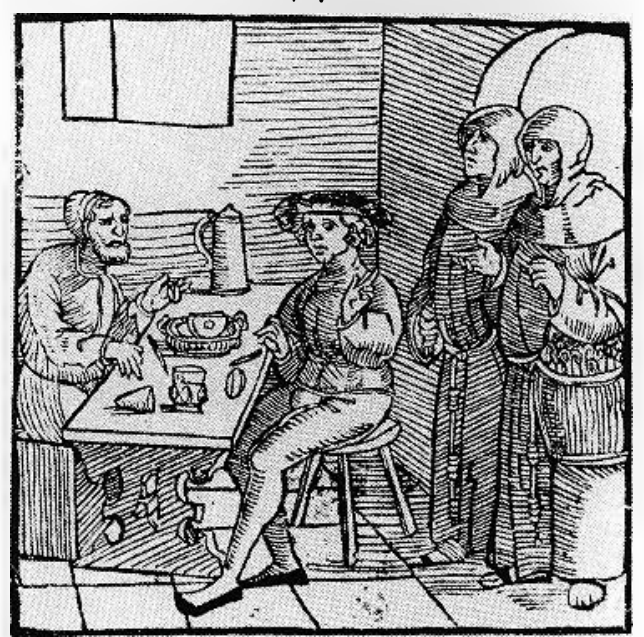

ï. Thimot.iu.

It thoubait wirt offinbar wer bels yedcrmant.

Figure 4. Erhard Schön. Eyn gesprech von den Scheinwercken der Geystlichen, 1524, title-page (Photo: Nuremberg, Stadtbibliothek). 


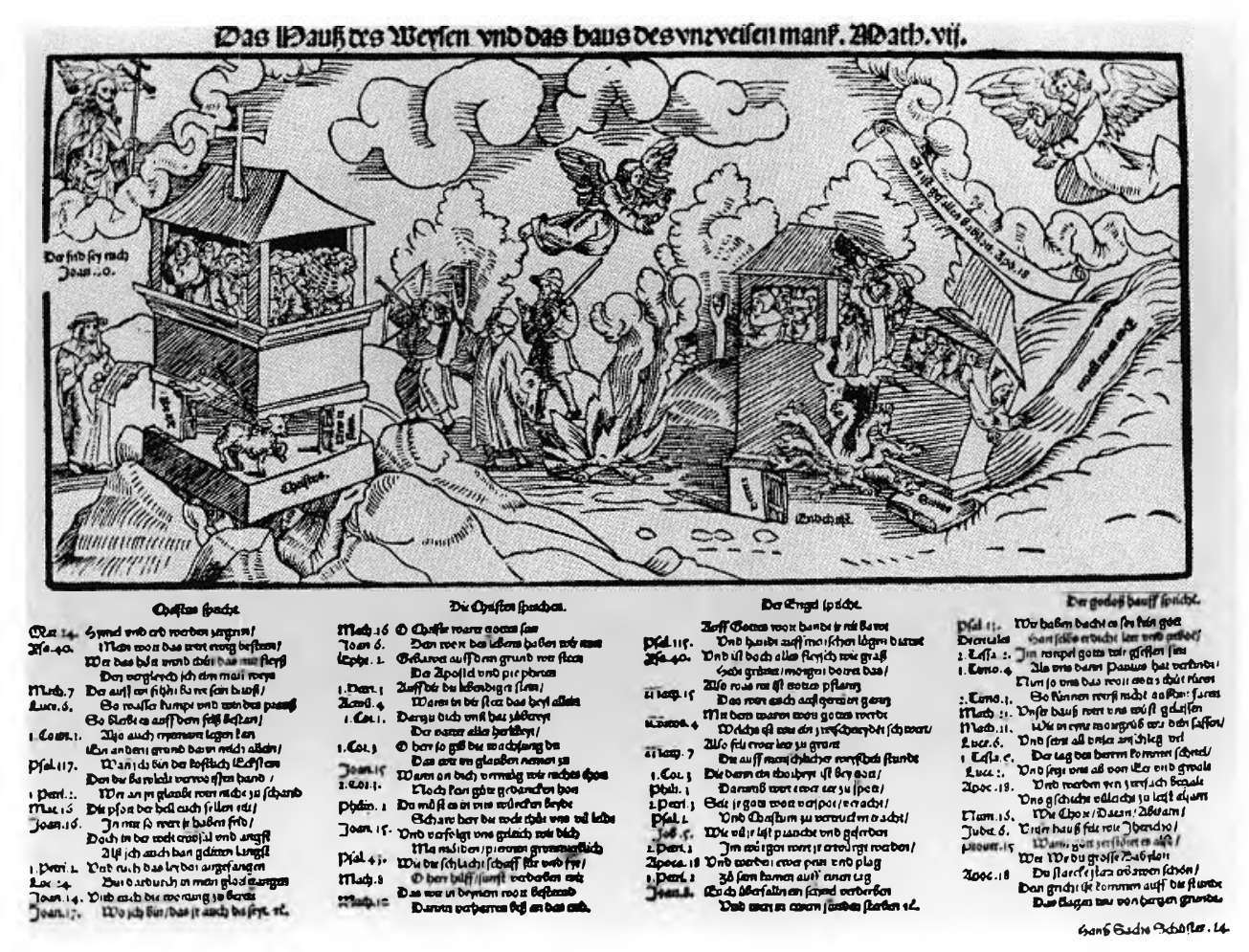

Figure 5. Erhard Schön. Das Hauss des Weysen und das haus des vnweisen manss, 1524, broadsheet (Photo: Berlin, Staatsbibliothek).

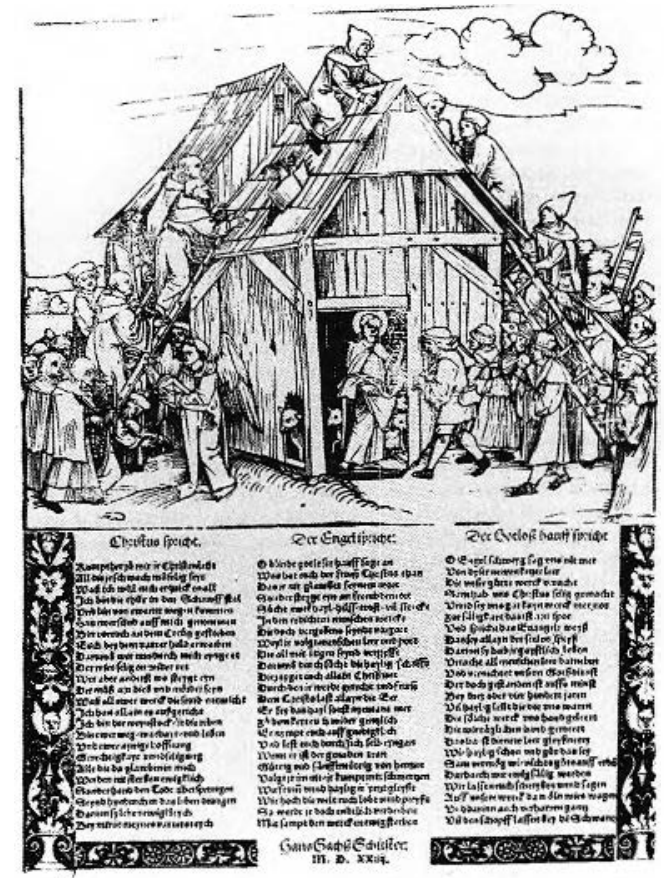

Figure 6. Copy after Sebald Beham. Der schafstal Christi, 1524, broadsheet (Photo: Berlin, Staatsbibliothek).

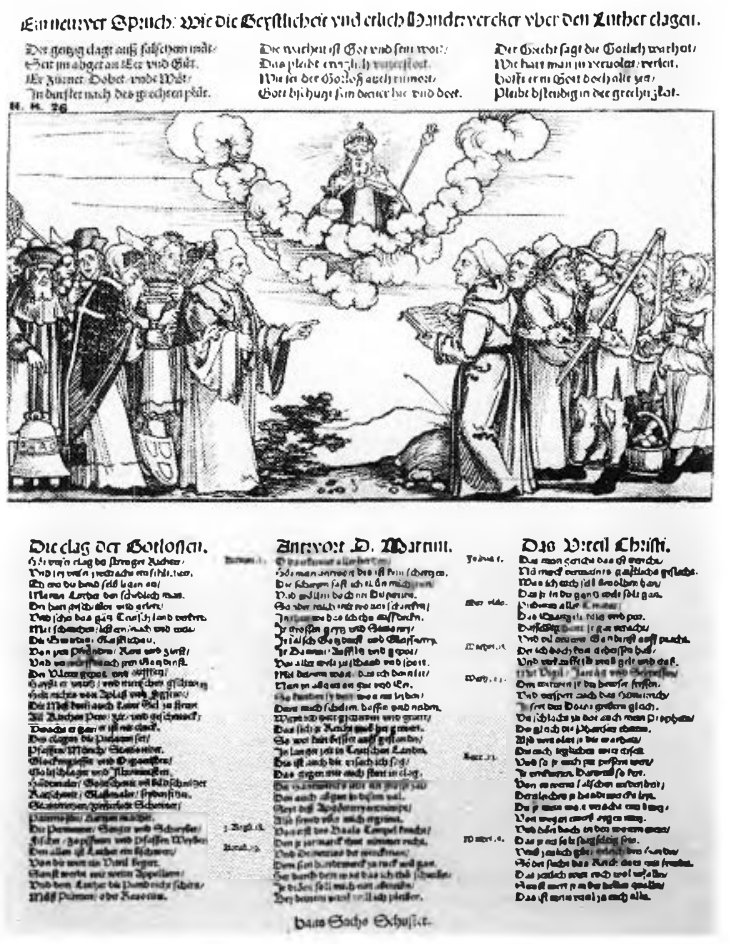

FIGURE 7. Sebald Beham. Geistlichkeit und Handwerker klagen über Luther, 1524, broadsheet (Photo: Nuremberg, Germanisches Nationalmuseum). 


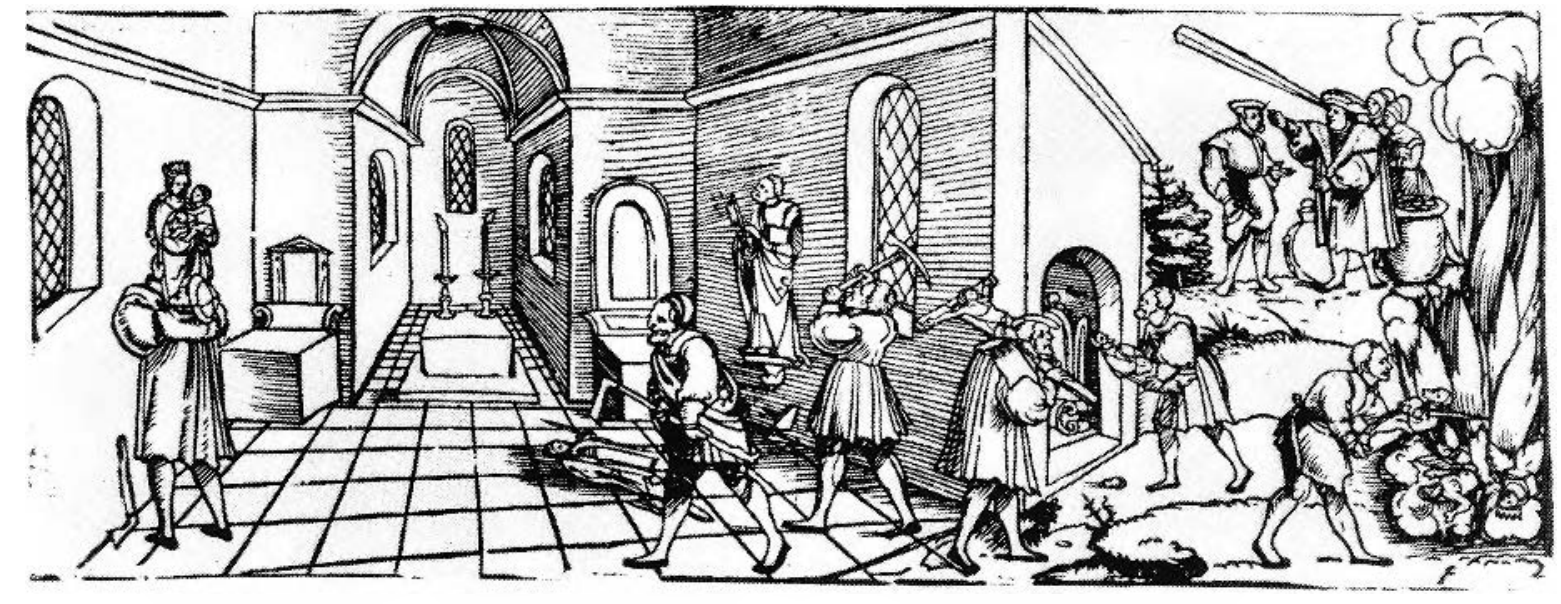

FiguRE 8. Erhard Schön. Klagrede der armen verfolgten Götzen und Tempelpilder, ca. 1530, broadsheet (Photo: Gotha, Schlossmuseum).

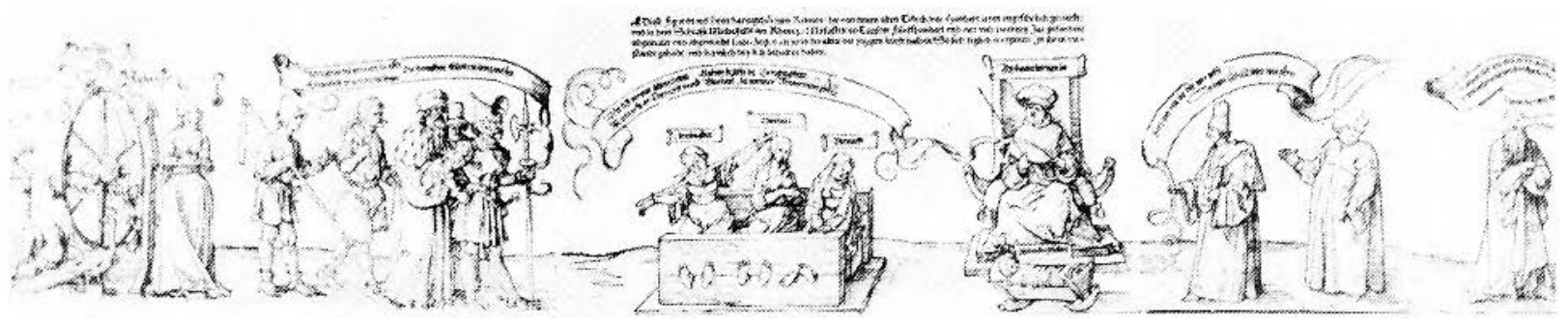

Figure 9. Albrecht Dürer, workshop. Michelfeld Tapestry, 1526, single-leaf woodcut (Photo: Nuremberg, Germanisches Nationalmuseum).

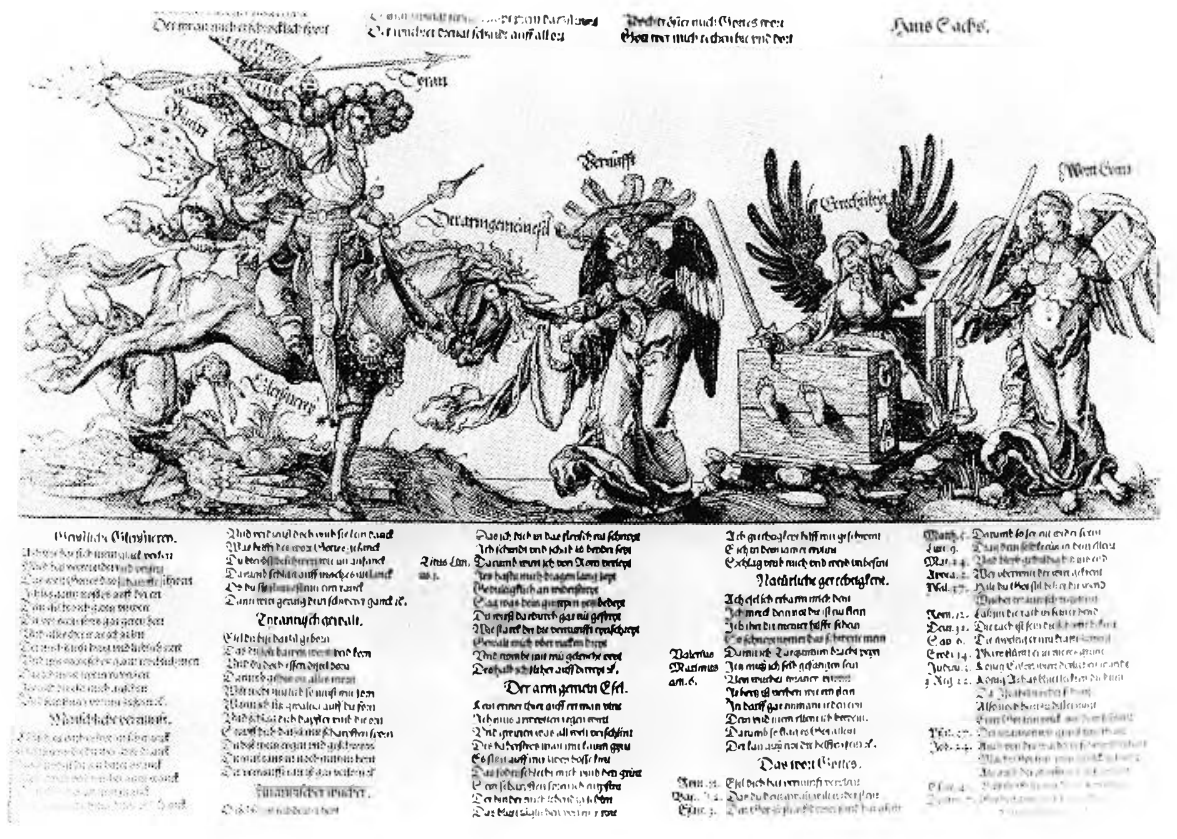

Figure 10. Peter Flötner. Tyrannei, Wucher und Gleisnerei, 1525 (Photo: Hamburg, Kunsthalle). 